\title{
Experimental and computational studies on structural transitions in the LiBH4-Lil pseudobinary system
}

Oguchi, H.; Matsuo, M.; Hummelshøj, Jens Strabo; Vegge, Tejs; Nørskov, Jens Kehlet; Sato, T.; Miura, Y.; Takamura, H.; Maekawa, H.; Orimo, S.

Published in:

Applied Physics Letters

Link to article, DOI:

$10.1063 / 1.3117227$

Publication date:

2009

Document Version

Publisher's PDF, also known as Version of record

Link back to DTU Orbit

Citation (APA):

Oguchi, H., Matsuo, M., Hummelshøj, J. S., Vegge, T., Nørskov, J. K., Sato, T., Miura, Y., Takamura, H., Maekawa, H., \& Orimo, S. (2009). Experimental and computational studies on structural transitions in the LiBH4Lil pseudobinary system. Applied Physics Letters, 94(14), 141912. https://doi.org/10.1063/1.3117227

\section{General rights}

Copyright and moral rights for the publications made accessible in the public portal are retained by the authors and/or other copyright owners and it is a condition of accessing publications that users recognise and abide by the legal requirements associated with these rights.

- Users may download and print one copy of any publication from the public portal for the purpose of private study or research.

- You may not further distribute the material or use it for any profit-making activity or commercial gain

- You may freely distribute the URL identifying the publication in the public portal 


\title{
Experimental and computational studies on structural transitions in the $\mathrm{LiBH}_{4}-$ Lil pseudobinary system
}

\author{
H. Oguchi, ${ }^{1,2}$ M. Matsuo, ${ }^{1}$ J. S. Hummelshøj, ${ }^{3,4}$ T. Vegge, ${ }^{3}$ J. K. Nørskov, ${ }^{4}$ T. Sato, ${ }^{1}$ \\ Y. Miura, ${ }^{1}$ H. Takamura, ${ }^{2}$ H. Maekawa, ${ }^{2}$ and S. Orimo ${ }^{1, a)}$ \\ ${ }_{1}^{1}$ Institute for Materials Research, Tohoku University, Sendai 980-8577, Japan \\ ${ }^{2}$ Graduate School of Engineering, Tohoku University, Sendai 980-8579, Japan \\ ${ }^{3}$ Materials Research Division, Ris $\phi$ National Laboratory for Sustainable Energy, \\ Technical University of Denmark, DK-4000 Roskilde, Denmark \\ ${ }^{4}$ Center for Atomic-scale Materials Design, Department of Physics, Technical University of Denmark, \\ DK-2800 Kgs. Lyngby, Denmark
}

(Received 4 March 2009; accepted 19 March 2009; published online 10 April 2009)

\begin{abstract}
Structural transition properties of the $\mathrm{LiBH}_{4}+x \mathrm{LiI}(x=0-1.00)$ pseudobinary system were examined by powder x-ray diffraction and differential scanning calorimetry combined with periodic density functional theory calculations. We experimentally and computationally confirmed the stabilization of the high-temperature [hexagonal, lithium super(fast-)ionic conduction] phase of $\mathrm{LiBH}_{4}$ with $x=0.33$ and 1.00 , and the results also imply the existence of intermediate phases with $x$ $=0.07-0.20$. The studies are of importance for further development of $\mathrm{LiBH}_{4}$ and the derived hydrides as solid-state electrolytes. (C) 2009 American Institute of Physics.
\end{abstract}

[DOI: 10.1063/1.3117227]

Lithium borohydride $\left(\mathrm{LiBH}_{4}\right)$ exhibits lithium super(fast-)ionic conductivity accompanied by a structural transition from low-temperature (LT, orthorhombic) to hightemperature (HT, hexagonal) phases by heating to approximately $390 \mathrm{~K}$. ${ }^{1}$ Since the structural transition is reversible, the HT phase with super(fast-)ionic conductivity transforms into the LT phase with lower conductivity by cooling to around $380 \mathrm{~K}$. It would thus be highly desirable to stabilize the HT phase (or to prohibit the formation of the LT phase by cooling in) of $\mathrm{LiBH}_{4}$ as a potential candidate of solid-state electrolytes at room temperature (RT).

It was recently suggested that the addition of lithium halides, ${ }^{2-4}$ especially LiI, ${ }^{3}$ stabilizes the HT phase of $\mathrm{LiBH}_{4}$ below $380 \mathrm{~K}$. For example, judging from the conductivity measurements, the hydride with a nominal composition of $\mathrm{LiBH}_{4}+0.33 \mathrm{LiI}$ showed no obvious structural transition from the HT to LT phases by cooling from $420 \mathrm{~K}$ down to RT. ${ }^{3}$ Accordingly, the value of the conductivity at RT increases from the order of $10^{-8} \mathrm{~S} / \mathrm{cm}$ for $\mathrm{LiBH}_{4}$ to that of $10^{-5} \mathrm{~S} / \mathrm{cm}$ for $\mathrm{LiBH}_{4}+0.33 \mathrm{LiI}$. Systematic studies about the structural transition of $\mathrm{LiBH}_{4}$ with and without LiI are highly required for further developments of $\mathrm{LiBH}_{4}$ and the derived hydrides as solid-state electrolytes.

The purpose of the present study is, therefore, to experimentally and computationally examine the LiI-composition dependence of the structural and thermodynamical properties of the $\mathrm{LiBH}_{4}+x \mathrm{LiI}(x=0-1.00)$ pseudobinary system.

The samples examined were synthesized from the powders of $\mathrm{LiBH}_{4}$ and LiI (both from Aldrich Co. Ltd.). Approximately $500 \mathrm{mg}$ of the powder mixture with nominal compositions of $\mathrm{LiBH}_{4}+x \mathrm{LiI}(x=0,0.07,0.14,0.20,0.33$, and 1.00) were mechanically milled for $5 \mathrm{~h}$ under Ar atmosphere. Then the samples were examined by powder X-ray diffraction (XRD, $\mathrm{Cu} K \alpha$ radiation, at RT) and differential scanning calorimetry (DSC, $5 \mathrm{~K} / \mathrm{min}$, under He atmosphere).

${ }^{a)}$ Electronic mail: orimo@imr.tohoku.ac.jp.
The samples were always handled in a glove box filled with purified Ar/He.

Periodic density functional theory (DFT) calculations were performed using the DACAPO planewave pseudopotential $\operatorname{code}^{5}$ and the atomic simulation environment implementation ${ }^{6}$ to investigate the relative ground state stabilities of the LT and HT phases in $\mathrm{LiBH}_{4}+x$ LiI. Ultrasoft pseudopotential are used to model the ionic cores and the exchange and correlation effects are described by the Perdew-Burke-Ernzerhof functional. ${ }^{5}$ The Kohn-Sham wave functions are expanded in a plane wave basis with a cutoff energy of $350 \mathrm{eV}$, and the first Brillouin zone is sampled on a $k$-point grid with a spacing of approximately $0.05 \AA^{-1}$ in all directions. Super cells containing 2-8 formula units (Li atoms) are used to describe the systems.

Figure 1 shows the powder XRD profiles of $\mathrm{LiBH}_{4}$ $+x$ LiI. The diffraction peak intensities of the LT phase of $\mathrm{LiBH}_{4}(x=0)$ drastically decrease with $x=0.07$. Only the peaks corresponding to the HT phase can be detected with $x=0.33$ and 1.00 . The tendencies are consistent with the results on the conductivity ${ }^{3}$ and the addition of LiI stabilizes the HT phase of $\mathrm{LiBH}_{4}$ at RT. The $\mathrm{LiBH}_{4}+x \mathrm{LiI}$ pseudobinary system probably forms $\mathrm{Li}\left(\mathrm{BH}_{4}-\mathrm{I}\right)$ solid solutions, similar to $\mathrm{Li}(\mathrm{Br}-\mathrm{I})$ in the $\mathrm{LiBr}+x \mathrm{LiI}$ system. ${ }^{8}$ The lattice constants of the HT phase ${ }^{9}(x=0,0.33$, and 1.00) summarized in Table I are found to increase with increasing $x$, as is well comparable with the previous estimation of the unit cell volumes. ${ }^{3}$

The thermodynamical properties of $\mathrm{LiBH}_{4}+x \mathrm{LiI}$ were examined by DSC and the results of the second heating process are shown in Fig. 2. The endothermic peaks directly indicate the structural transition. (The single peak in each sample might prove its compositional homogeneity.) Both the peak temperatures (onset) and enthalpy changes (areas ${ }^{11}$ ) decrease by up to $x=0.20$, and the values are summarized in Table I. No endothermic peak was detected over $x=0.33$, indicating the HT phase is stabilized at RT. It should be 


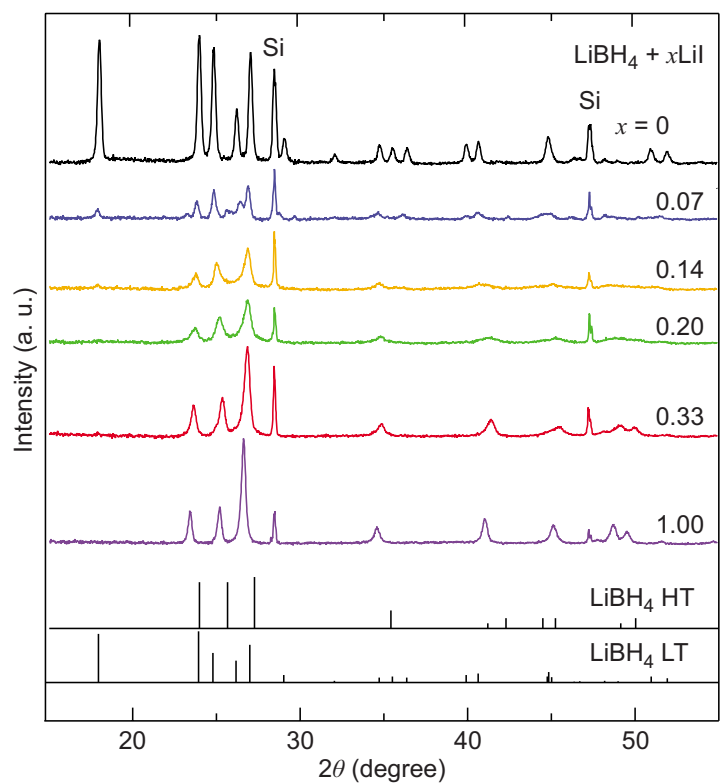

FIG. 1. (Color online) Powder XRD profiles of $\mathrm{LiBH}_{4}+x \mathrm{LiI}(x=0-1.00)$. The diffraction peaks are calibrated by Si internal standard. The standard diffraction peaks of the LT (orthorhombic) and HT (hexagonal) phases of $\mathrm{LiBH}_{4}$ are shown for reference (Ref. 7).

noted that no change was observed in the DSC profiles for $x=0.33$ even after 10 and 20 heating/cooling cycles (heating up to $423 \mathrm{~K}$ and cooling down to RT), as shown in Fig. 2; the cyclic property is preferable for solid-state electrolytes.

The structural transition temperatures obtained from Fig. 2 and summarized in Table I were plotted as a function of $x$ (top axis) and of "LiI mol\%" (bottom axis), as shown in Fig. 3. We can confirm the stabilization feature of the HT phase in the $\mathrm{LiBH}_{4}+x$ LiI pseudobinary system. Near-linear decrease of the structural transition temperatures might be due to increased neighboring $\left[\mathrm{BH}_{4}\right]^{-}$distance $^{12}$ and to induced lattice anharmonicity ${ }^{9,13,14}$ by $\mathrm{I}^{-}$substitution [ionic radius of $\left.\mathrm{I}^{-}(0.211 \mathrm{~nm})>\left[\mathrm{BH}_{4}\right]^{-}(0.205 \mathrm{~nm})\right] .^{15}$

The enthalpy changes of the structural transition from the LT to HT phases were also determined by periodic DFT calculations and summarized in Table I. Tendencies of both the computational and experimental (from DSC) values show good agreement, that is, a monotonous decrease with increasing $x$. However, the decrease in the computational values up to $x=0.33$ is not as pronounced as in the experiments.

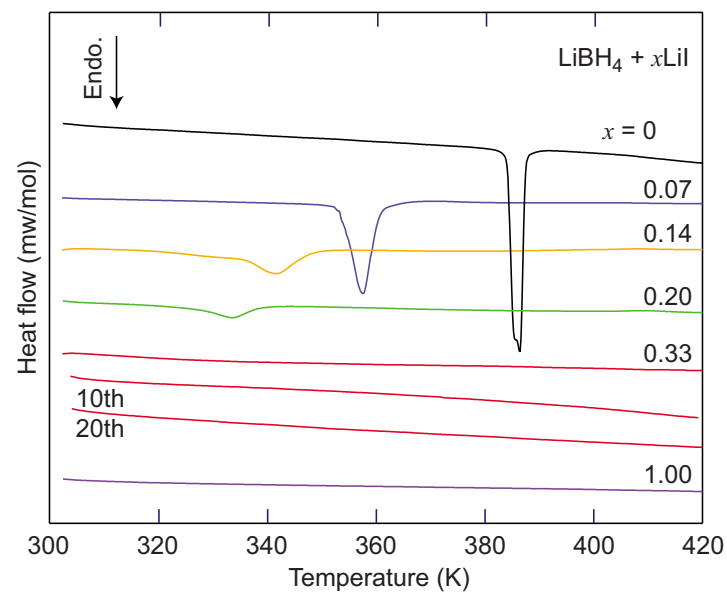

FIG. 2. (Color online) DSC profiles of $\mathrm{LiBH}_{4}+x \mathrm{LiI}$. The intensities are normalized to show the heat flow per mole of the formula unit of $\mathrm{LiBH}_{4}$ $+x$ LiI. The area of the endothermic peak of each profile gives the experimental value of the enthalpy change $\left(\Delta H_{\text {exp. }}\right)$, e.g., $4.18 \mathrm{~kJ} / \mathrm{mol}$ with $x=0$.

So far, a number of the crystalline structures of $\mathrm{LiBH}_{4}$ have been proposed and studied. ${ }^{7,16-23}$ In the $\mathrm{LiBH}_{4}+x \mathrm{LiI}$ pseudobinary system, possible intermediate (IM) phases are predicted to be stable at low $x$-values and a crystalline structure of the IM phase with $x=0.14$ is shown in Fig. 4 . The corresponding enthalpy change from the IM to HT phases, 2.3 $\mathrm{kJ} / \mathrm{mol}$, as in Table I, shows better agreement with the experiment. The powder XRD profiles were indexed (using indexing programs TREOR $90^{24}$ and PIRUM ${ }^{25}$ ) by orthorhombic unit cell for $x=0$ and by hexagonal one for $x=0.33$ and 1.00 , but both unit cells lead to significant errors for $x$ $=0.07-0.20{ }^{26}$ The indexing results imply the existence of the IM phases, as was predicted by the DFT calculations. The details of the structural and thermodynamical properties of the IM phases are under investigation.

In summary, the powder XRD and DSC combined with the periodic DFT calculations revealed the structural and thermodynamical properties of the $\mathrm{LiBH}_{4}+x \mathrm{LiI}(x$ $=0-1.00)$ pseudobinary system. The HT [hexagonal, lithium super(fast-)ionic conduction] phase of $\mathrm{LiBH}_{4}$ can be stabilized with $x=0.33$ and 1.00 . Also, no significant change was observed in the DSC profiles for $x=0.33$ even after 10 and 20 heating/cooling cycles. The experimental and computational results imply the existence of IM phases with $x$ $=0.07-0.20$.

TABLE I. Lattice constants, $a$ and $c$, of the HT [hexagonal, lithium super(fast-)ionic conduction] phase for $x=0,0.33$, and 1.00; structural transition temperature $T_{s}$; and experimental and computational values of enthalpy change, $\Delta H_{\text {exp. }}$ and $\Delta H_{\text {theo. }}$ (calculated for the transition from the LT to HT phases); for $\mathrm{LiBH}_{4}+x \mathrm{LiI}$, value of $\Delta H_{\text {theo. }}$ in square bracket was calculated for the transition from the IM to HT phases using a possible IM phase of LiBH +0.14LiI (shown in Fig. 4). Lattice constants for $x=0.07,0.14$, and 0.20 are left blank as none of them are indexed by orthorhombic and hexagonal unit cells. Lattice constants of (hexagonal-)LiI are also added for reference.

\begin{tabular}{|c|c|c|c|c|c|}
\hline$x$ in $\mathrm{LiBH}_{4}+x \mathrm{LiI}$ & $\begin{array}{c}a \\
(\AA)\end{array}$ & $\begin{array}{c}c \\
(\AA)\end{array}$ & $\begin{array}{c}T_{s} \\
(\mathrm{~K})\end{array}$ & $\underset{(\mathrm{kJ} / \mathrm{mol})}{\Delta H_{\text {exp. }}}$ & $\begin{array}{c}\Delta H_{\text {theo. }} \\
(\mathrm{kJ} / \mathrm{mol})\end{array}$ \\
\hline 0 & $4.24 \pm 0.02^{\mathrm{a}}$ & $6.87 \pm 0.03^{\mathrm{a}}$ & $384 \pm 3$ & $4.18^{\mathrm{b}}$ & 7.7 \\
\hline 0.07 & $\ldots$ & $\ldots$ & $354 \pm 3$ & $3.5 \pm 0.3$ & $\ldots$ \\
\hline 0.14 & $\cdots$ & $\cdots$ & $334 \pm 3$ & $2.6 \pm 0.1$ & $6.3[2.3]$ \\
\hline 0.20 & $\cdots$ & $\cdots$ & $326 \pm 3$ & $1.0 \pm 0.3$ & $\cdots$ \\
\hline 0.33 & $4.354 \pm 0.002$ & $7.035 \pm 0.005$ & $\cdots$ & $\cdots$ & 6.2 \\
\hline 1.00 & $4.389 \pm 0.001$ & $7.073 \pm 0.003$ & $\cdots$ & $\cdots$ & 0.0 \\
\hline LiI & $4.514 \pm 0.001^{\mathrm{c}}$ & $7.311 \pm 0.002^{\mathrm{c}}$ & $\cdots$ & $\cdots$ & $\cdots$ \\
\hline
\end{tabular}

${ }^{\mathrm{a}}$ Reference 9 .

${ }^{\mathrm{b}}$ Reference 11 .

${ }^{\mathrm{c}}$ Reference 10. 


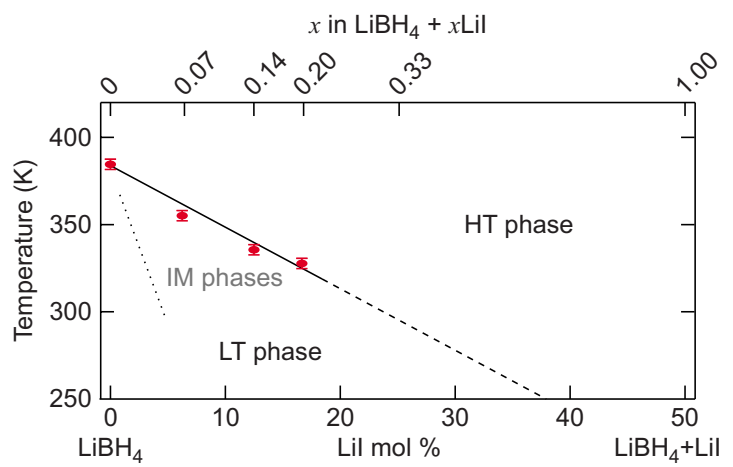

FIG. 3. (Color online) Structural transition temperatures of $\mathrm{LiBH}_{4}+x \mathrm{LiI}$ as a function of value $x$ (top axis) and LiI mol\% (bottom axis). The IM phases are predicted with $x=0.07-0.20$.

We are grateful to Professor Hiroki Kuwano for valuable discussion. This work was partially supported by KAKENHI the Creative Scientific Research Program (Grant No. 18GS0203: Study of nanoenergy system creation), the Global-COE Program "Materials Integration (Tohoku University)," the Integrated Project of ICC-IMR, European Commission DG Research (Grant No. SES6-2006-51827/ NESSHy), and Danish Center for Scientific Computing (DCSC) the Lundbeck Foundation.

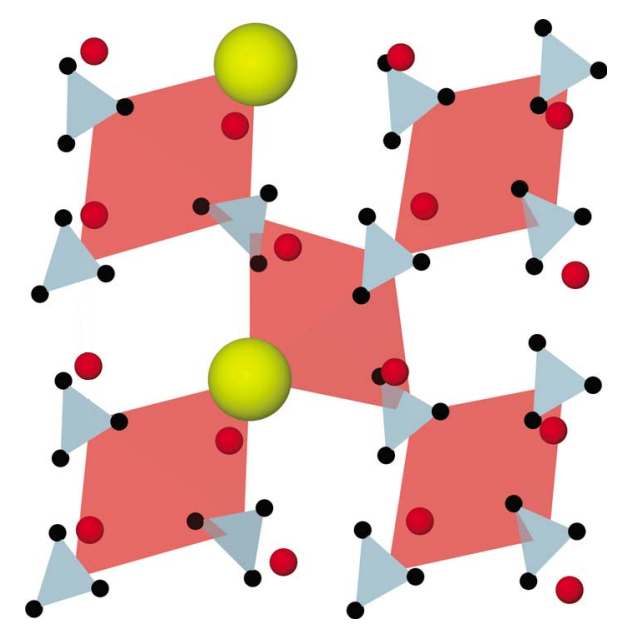

FIG. 4. (Color online) Crystalline structure of a possible IM phase of $\mathrm{LiBH}_{4}+0.14 \mathrm{LiI}$ (in LiI space group $P 4_{2} / \mathrm{mnm}$ ). Red, yellow, and black circles correspond to $\mathrm{Li}, \mathrm{I}$, and $\mathrm{H}$ sites, respectively. $\mathrm{B}$ atoms are embedded in blue $\left[\mathrm{BH}_{4}\right]^{-}$tetrahedron.
${ }^{1}$ M. Matsuo, Y. Nakamori, S. Orimo, H. Maekawa, and H. Takamura, Appl. Phys. Lett. 91, 224103 (2007).

${ }^{2}$ L. Mosegaard, B. Møller, J. E. Jørgensen, Y. Filinchuk, Y. Cerenius, J. C. Hanson, E. Dimasi, F. Besenbacher, and T. R. Jensen, J. Phys. Chem. C 112, 1299 (2008).

${ }^{3}$ H. Maekawa, M. Matsuo, H. Takamura, M. Ando, Y. Noda, T. Karahashi, and S. Orimo, J. Am. Chem. Soc. 131, 894 (2009).

${ }^{4}$ M. Matsuo, H. Takamura, H. Maekawa, H.-W. Li, and S. Orimo, Appl. Phys. Lett. 94, 084103 (2009).

${ }^{5}$ B. Hammer, L. B. Hansen, and J. K. Nørskov, Phys. Rev. B 59, 7413 (1999)

${ }^{6}$ S. R. Bahn and K. W. Jacobsen, Comput. Sci. Eng. 4, 56 (2002).

${ }^{7}$ J.-Ph. Soulié, G. Renaudin, R. Černý, and K. Yvon, J. Alloys Compd. 346, 200 (2002).

${ }^{8}$ J. Sangster and A. D. Pelton, J. Phys. Chem. Ref. Data 16, 509 (1987).

${ }^{9}$ The values of the lattice constants for $x=0(300 \mathrm{~K})$ are extrapolated ones of the HT (hexagonal) phase of $\mathrm{LiBH}_{4}$ at $381-500 \mathrm{~K}$ in Y. Filinchuk, D. Chernyshov, and R. Černý, J. Phys. Chem. C 112, 10579 (2008).

${ }^{10}$ D. Fischer, A. Müller, and M. Jansen, Z. Anorg. Allg. Chem. 630, 2697 (2004)

${ }^{11}$ Experimental values of enthalpy change for the structural transition are normalized by the one reported for $x=0(4.18 \mathrm{~kJ} / \mathrm{mol})$; A. Züttel, A. Borgschulte, and S. Orimo, Scr. Mater. 56, 823 (2007); S. Orimo, Y. Nakamori, J. R. Eliseo, A. Züttel, and C. M. Jensen, Chem. Rev. (Washington, D.C.) 107, 4111 (2007).

${ }^{12}$ C. C. Stephenson, D. W. Rice, and W. H. Stockmayer, J. Chem. Phys. 23 1960 (1955).

${ }^{13}$ F. Buchter, Z. Łodziana, Ph. Mauron, A. Remhof, O. Friedrichs, A. Borgschulte, A. Züttel, D. Sheptyakov, Th. Strässle, and A. J. Ramirez-Cuesta, Phys. Rev. B 78, 094302 (2008).

${ }^{14}$ A.-M. Racu, J. Schoenes, Z. Łodziana, A. Borgschulte, A. Züttel, and J. Phys, Chem. Anal. 112, 9716 (2008).

${ }^{15}$ CRC Handbook of Chemistry and Physics, 88 th ed., edited by D. R. Lide (CRC, Boca Raton, 2007), pp. 12-27.

${ }^{16}$ Z. Łodziana and T. Vegge, Phys. Rev. Lett. 93, 145501 (2004).

${ }^{17}$ Z. Łodziana and T. Vegge, Phys. Rev. Lett. 97, 119602 (2006)

${ }^{18}$ K. Miwa, N. Ohba, S. Towata, Y. Nakamori, and S. Orimo, Phys. Rev. B 69, 245120 (2004)

${ }^{19}$ T. J. Frankcombe, G. J. Kroes, and A. Züttel, Chem. Phys. Lett. 405, 73 (2005)

${ }^{20}$ M. R. Hartman, J. J. Rush, T. J. Udovic, R. C. Bowman, Jr., and S.-J. Hwang, J. Solid State Chem. 180, 1298 (2007).

${ }^{21}$ L. Mosegaard, B. Møller, J. E. Jørgensen, U. Bösenberg, M. Dornheim, J. C. Hanson, Y. Cerenius, G. Walker, H. J. Jakobsen, F. Besenbacher, and T. R. Jensen, J. Alloys Compd. 446, 301 (2007)

${ }^{22}$ N. A. Zarkevich and D. D. Johnson, Phys. Rev. Lett. 100, 040602 (2008).

${ }^{23}$ V. Dmitriev, Y. Filinchuk, D. Chernyshov, A. V. Talyzin, A. Dzwilewski, O. Andersson, B. Sundqvist, and A. Kurnosov, Phys. Rev. B 77, 174112 (2008).

${ }^{24}$ P.-E. Werner, L. Eriksson, and M. Westdahl, J. Appl. Crystallogr. 18, 367 (1985)

${ }^{25}$ P.-E. Werner, Ark. Kemi 31, 513 (1969).

${ }^{26}$ For example, assuming the hexagonal phase, averaged deviation in $2 \theta$ is 0.14 for $x=0.14$, which is significantly larger than 0.02 for $x=0$ with orthorhombic one. 